\title{
DISRUPSI DAN MASA DEPAN PROFESI HUKUM
}

\author{
Widodo Dwi Putro* \\ Fakultas Hukum Universitas Mataram \\ Jalan Majapahit Nomor 62, Mataram, Nusa Tenggara Barat, 83125
}

\begin{abstract}
Disruption poses a threat on legal profession establishments such as law firms, notaries, as well as the courts. In the past, law used to be perceived as a complicated matter to laypersons and thus people dealing with the law required legal consultants in the past. However, artificial intelligence capable of resolving various legal issues has now become readily available making it unnecessary for people to consult with law firms. The main question is, why is artificial intelligence capable of replacing the human legal profession? In an effort to answer the said question, the research method looks at previous research predicting the occurrence of disruption in the area of law. The researcher also considers the most recent developments in the "competition" between the human legal profession and artificial intelligence. Any technology is bound to be replaced by an even more sophisticated technology, hence the legal profession applying a mechanical legal process is inevitably going to be replaced with speedier and more accurate artificial intelligence.
\end{abstract}

Keywords: disruption, legal profession, artificial intelligence, technology

\section{Intisari}

Disrupsi mengancam kemapanan profesi hukum seperti kantor-kantor advokat, notaris, dan juga pengadilan. Jika sebelumnya, hukum terasa rumit bagi banyak orang awam sehingga memerlukan konsultan hukum bagi yang berurusan dengan hukum, kini telah tersedia artificial intelligence yang mampu memecahkan berbagai persoalan hukum sehingga orang tidak perlu konsultasi ke kantor hukum. Pertanyaan mendasar, mengapa artificial inttelligence dapat menggantikan profesi hukum manusia? Untuk menjawab pertanyaan itu, Penulis menelusuri penelitian-penelitian sebelumnya yang memprediksi munculnya disrupsi di bidang hukum. Penulis juga melihat perkembangan terbaru "kompetisi" antara profesi hukum manusia dan artificial intelligence. Teknologi yang lebih canggih akan menggantikan sesuatu yang bersifat teknologi pula, maka profesi hukum yang cara berhukumnya mekanis akan digantikan oleh artificial intelligence yang lebih cepat dan akurat.

Kata kunci: disrupsi, profesi hukum, kecerdasan buatan, teknologi

\section{Pokok Muatan}

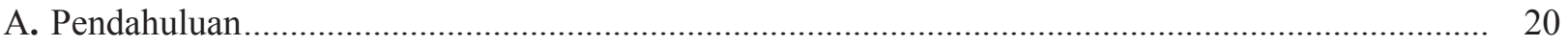

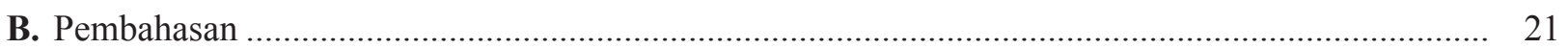

1. Profesi Hukum Manusia Versus Kecerdasan Buatan.................................................................. 21

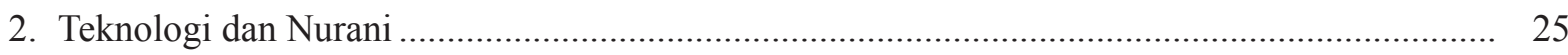

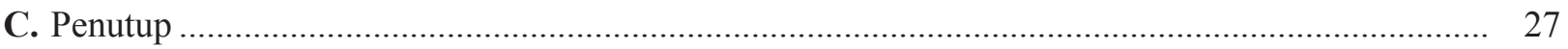

Alamat korespondensi: widodo.fhunram@gmail.com 


\section{A. Pendahuluan}

Gelombangperubahanituselalumengejutkan. Setelah kita melewati tren yang begitu panjang, tiba-tiba kita menghadapi perubahan yang berbeda sama sekali polanya. Seperti kini, dunia memasuki era disrupsi. Bagi yang tidak siap, disrupsi seperti tsunami yang menjungkirbalikan apa saja, bahkan sejumlah bisnis raksasa yang tidak inovatif.

Jauh sebelumnya, pada tahun 1967, Presiden American Bar Association, Charles S. Rhyne, dengan percaya diri bahwa computer tidak akan menggantikan para profesi hukum dengan mengatakan: "To allay unfounded fears, it should be stated that the computer will never replace the trained legal mind.The computer is incapable of original thought, reasoning and creative achievement". ${ }^{1}$ Tetapi revolusi 4.0. dengan kemajuan digitalnya dan hadirnya mesin kecerdasan buatan serta big data merubah paradigma dan cara orang berhukum menjadi "alarm" disrupsi bagi profesi hukum terutama kantor-kantor advokat, notaris, dan juga pengadilan yang sebelumnya tak tersentuh sama sekali. ${ }^{2}$

Merespon 'alarm' disrupsi tersebut, para praktisi hukum pun berkumpul dalam Techlaw Fest 2018 di Suntec Singapore Convention \& Exhibition Centre. Kecemasan mereka adalah suatu saat para pihak yang berperkara mungkin tidak lagi membutuhkan advokat, notaris, dan konsultan hukum sebagai penyedia jasa layanan hukum. Pengguna jasa hukum, mulai dari konsultasi hukum, pembuatan kontrak bisnis, hingga beracara dalam perkara di pengadilan bisa memilih beragam kecerdasan buatan yang mulai marak dikembangkan. ${ }^{3}$ Sebagaimana dunia bisnis, di era disrupsi, teknologi menggilas siapa saja yang tidak inovatif dan efisien, termasuk dunia advokat dan notaris yang telah menjadi industri-bisnis.

Jika sebelumnya, pendapat dan nasihat hukum terasa rumit bagi banyak orang awam sehingga kehadiran konsultan hukum sangat dibutuhkan bagi mereka yang berurusan dengan hukum. Kini, telah tersedia kecerdasan buatan yang menyediakan segala data, regulasi, yurisprudensi, sehingga orang yang berperkara tidak perlu konsultasi dengan datang ke kantor hukum. Cukup klik artificial intelligence untuk memperoleh informasi dan opini atas masalah hukum. Tersedia pula kecerdasan buatan yang mampu menyusun rancangan kontrak lengkap cukup dengan memproses input data, syarat dan ketentuan, para pihak dapat menyusun kontrak itu secara mandiri.

Jika kecerdasan buatan sudah cukup menolong dan menjawab masalah hukumnya dengan akurat, cepat, praktis, dan murah maka pengguna jasa hukum tentu akan mencari biaya yang lebih efisien, sehingga tidak lagi tertarik menggunakan jasa kantor hukum. Apakah kita akan memasuki dunia hukum pasca-manusia? Sejumlah advokat, misalnya T.M. Luthfi Yazid, advokat yang berkantor di Jakarta melihat disrupsi di bidang hukum dengan hadirnya mesin kecerdasan buatan sebagai ancaman sekaligus juga peluang bagi yang mampu melakukan inovasi. ${ }^{4}$ Sementara Nur Saifur Rauf, advokat yang berkantor di Kota Malang melihat kemunculan mesin kecerdasan bukan menggantikan advokat manusia melainkan justru membantu pekerjaan para praktisi hukum sehingga lebih akurat dan cepat. $^{5}$ Sedangkan advokat Burhanudin yang berkantor di Mataram lebih mencemaskan hadirnya mesin kecerdasan buatan yang diprediksikan dalam waktu yang tidak lama mengambil alih sebagian pekerjaan para praktisi hukum. ${ }^{6}$

\footnotetext{
Charles S. Rhyne, "The Computer Will Speed a Law-Full World", American Bar Association Journal, Vol. 53, May 1967, hlm. 423.

Richard Susskind, et al., 2015, The Future of The Professions: How Technology Will Transform the Work of Human Experts, Oxford University Press, Oxford, hlm. 279.

Hukumonline, “Artificial Intelligence dalam Industri Hukum, Menyongsong Masa Depan Dunia Hukum Tanpa Hakim dan Lawyer?”, https:// www.hukumonline.com/berita/baca/lt5ac7289c0b372/artificial-intelligence-dalam-industri-hukum--menyongsong-masa-depan-duniahukum-tanpa-hakim-dan-lawyer, diakses 12 November 2018.

Hasil Wawancara dengan T.M. Luthfi Yazid, Direktur InLaw Center, pada 5 Januari 2019.

Hasil Wawancara dengan Nur Saifur Rauf, Advokat Nur Saifur Rauf, S.H. \& Partners, pada 20 Desember 2018

Hasil Wawancara dengan Burhanudin, Advokat AB \& Partners, pada 17 Desember 2018.
} 
Kekhawatiran para advokat tersebut beralasan karena penggunaan robot kercerdasan buatan telah menggantikan peran advokat manusia seperti robot Ross yang dipakai lawfirm Baker Hostetler di Washington untuk menangani perkara kepailitan. Ross adalah pengacara robot kecerdasan buatan pertama di dunia. Namun, Bob Craig dan Andrew Arruda selaku Chief Information Officer dan Chief Executive Ross Inteligence berusaha "menenangkan" bahwa Ross tidak dimaksudkan untuk mengganti pengacara, hanya untuk mempercepat pengacara dalam belajar ketimbang berjam-jam membuka link internet, membaca beratus-ratus halaman kasus tanpa hasil maksimal. ${ }^{7}$

Kebangkitan kecerdasan buatan dan disrupsi dibidang hukum mendorong orang mempertanyakan eksistensi paradigma profesi hukum: mengapa artificial intelligence dapat menggantikan profesi hukum manusia? Untuk menjawab pertanyaan mengapa peran profesi hukum terancam digantikan oleh perangkat kecerdasan buatan, Penulis menelusuri penelitian-penelitian sebelumnya yang memprediksi munculnya disrupsi di bidang hukum. Penulis juga melihat perkembangan "kompetisi" antara profesi hukum manusia dan mesin kecerdasan buatan.

Sebagaimana penelitian filsafat hukum, pendekatannya bersifat spekulatif dan self evident ${ }^{8}$, memahami kebangkitan mesin kecerdasan tidak berhenti hanya pada masalah teknis hukum melainkan juga memeriksa filsafat dan teori hukum, ${ }^{9}$ serta kemungkinan-kemungkinan terjadinya pergeseran paradigma, berserta penyebabnya. Penelitian ini merupakan studi 'pemikiran atas pemikiran', di mana Penulis menelisik cara bernalar suatu paradigma dalam praktik hukum yang serupa dengan "cara bernalar" teknologi sehingga dianalisis mengapa cara berpikir profesi hukum manusia dapat digantikan robot atau mesin kecerdasan buatan.

Penelitian ini memiliki semacam "asumsi dasar", bahwa masyarakat terus berkembang, ada masalah-masalah baru yang muncul, sehingga ketika suatu paradigma tidak dapat menyelesaikan masalah-masalah tersebut, paradigma lama itu mulai diragukan sehingga terjadi situasi anomali. Ketika anomali itu terus semakin melebar dan terjadi krisis, maka untuk memahaminya Penulis perlu memeriksa krisis paradigma tertentu dibalik fenomena disrupsi di bidang hukum tersebut. ${ }^{10}$ Untuk melihat disrupsi dan pergeseran paradigma di bidang hukum, maka Penulis perlu mendialogkan secara ekstrapolatif antara paradigma hukum di ranah ideal (law as what ought to be) dan kenyataan perkembangan praktik hukum di masyarakat dengan keberadaan mesin kecerdasan buatan (law in context).

\section{B. Pembahasan}

\section{Profesi Hukum Manusia Versus Kecer- dasan Buatan}

Pengetahuan adalah basis dibangunnya premis-premis atau dalil-dalil umum sains, yang untuk selanjutnya sains akan berperan sebagai "ibu kandung": dari kelahiran teknologi. Teknologi yang sebelumnya dipandang sebagai produkproduk "hilir" yang dihasilkan manusia, kini justru berkompetisi dengan manusia. Dalam suatu penelitian terungkap untuk pertama kalinya dalam sebuah kompetisi tingkat akurasi mesin kecerdasan buatan lebih akurat dibanding advokat manusia. Perangkat kecerdasan buatan bernama LawGeex

\footnotetext{
Lihat Karen Turner, "Meet "Ross” The Newly Hired Legal Robot”, The Washington Post, 16 Mei 2016.

Soetandyo Wignjosoebroto, "Konsep Hukum, Tipe dan Metode Penelitiannya," Makalah, disampaikan pada Penataran Metodologi Penelitian Hukum di Fakultas Hukum Universitas Hasanudin, Makasar, 4- 5 Februari 1994, hlm. 3.

Lihat Michał Araszkiewicz, et al., 2013, Coherence: Insights from Philosophy, Jurisprudence and Artificial Intelligence, Springer, hlm. vi.

1 Paradigma secara sederhana dapat diartikan sebagai "cara pandang". Paradigma seperti "jendela" dalam melihat suatu realitas; bagaimana cara kita melihat sesuatu, apa yang kita anggap masalah, serta apa metode untuk memecahkan. Pengertian yang lebih akademis, paradigma diartikan sebagai satu kerangka referensi atau pandangan yang menjadi satu dasar keyakinan atau pijakan suatu paradigma. Menurut pandangan Thomas Kuhn, paradigma bukan bangunan yang statis. melainkan "bergerak" dan "bergeser" (paradigm shift). Dalam dunia keilmuan, pergeseran dari paradigma satu ke paradigma lain, bukan bergerak seperti garis yang lurus, melainkan melalui keraguan, krisis, bahkan guncangan-guncangan.
} 
"diadu" dengan 20 advokat terkemuka di Amerika Serikat dalam mengidentifikasi 30 masalah hukum dan diberi waktu selama empat jam. Adapun permasalahan hukumnya meliputi penyelesaian suatu sengketa arbitrase hingga masalah ganti rugi. ${ }^{11}$

Penelitian tersebut menilai seberapa akurat Lawgeex dalam mengidentifikasi dan menangani suatu masalah hukum dibandingkan advokat manusia. Hasil riset menunjukan, advokat manusia mencapai nilai rata-rata akurasi sebesar $85 \%$, sedangkan Lawgeex mencapai tingkat akurasi hingga 94\% dalam mereview dan mengidentifikasi masalah hukum. Penelitian tersebut juga mengukur dan membandingkan dari segi waktu, yaitu seberapa cepat mesin kecerdasan buatan tersebut mampu mereview 5 (lima) perjanjian (Non-Disclosure Agreements) dibandingkan dengan advokat berpengalaman tersebut untuk mengevaluasi objek perjanjian yang sama. Hasilnya, advokat manusia membutuhkan waktu rata-rata 92 menit, sedangkan Lawgeex hanya membutuhkan waktu rata-rata 26 detik. Dalam situs tersebut, perangkat kecerdasan buatan itu mengolok-olok para advokat mengapa ia lebih cepat sambil berseloroh: "robots don't need coffee." 12

Kemampuan manusia menjadi kurang relevan sehingga dalam beberapa hal digantikan sistem algoritma. ${ }^{13}$ Sekarang perlu dicari tahu, mengapa perangkat kecerdasan buatan lebih cerdas daripada profesi hukum yang dijalankan manusia dan apakah peran profesi hukum dapat diganti dengan peran perangkat kecerdasan buatan? Pertama, beberapa perkembangan teknologi seperti digital documents, data processing, chatbots, flexible working, dan predictive analytics, makin mendorong percepatan disrupsi di bidang hukum. Alat-alat teknologi canggih tersebut diprogram dapat menampung segala peraturan hukum dan yurisprudensi, bahkan mampu memberikan berbagai opini hukum atas beragam masalah hukum yang ditanyakan. ${ }^{14}$ Tentu, korban pertama yang tergilas oleh perangkat kecerdasan buatan adalah para sarjana hukum yang hanya mengandalkan hafalan peraturan perundangundangan dan prosedur hukum.

Kedua, potensi korban selanjutnya adalah notaris dan konsultan hukum. Untuk profesi hukum, ada pengaturan yang ketat, misalnya syarat khusus untuk menjadi notaris dan advokat. Orang bisa mengatakan hari ini mesin kecerdasan bukanlah kompetitor bagi notaris karena hukum mengatur absahnya suatu perjanjian mensyaratkan akta notaris misalnya pendirian Perseroan Terbatas, perjanjian fidusia, dan sebagainya. Bisa dibayangkan, bagiamana profesi notaris jika masa depan hukum tidak menentukan absahnya perjanjian tertentu harus melalui notaris, maka pekerjaan hukum yang bersifat teknis seperti menyusun perjanjian atau kontrak akan mudah digantikan mesin kecerdasan buatan. Para pihak yang berkontrak cukup dengan bantuan mesin kecerdasan buatan, dapat menyusun kontrak bisnis secara mandiri dalam aplikasi internet di depan komputer cukup dengan memproses input data syarat dan ketentuan dari para pihak.

Ketiga, perkembangan digitalisasi mungkin juga akan menggilas jasa konsultan hukum karena perusahaan tidak lagi membutuhkannya setelah peran itu digantikan mesin kecerdasan buatan.

11 Kecerdasan buatan merupakan produk hasil buatan manusia yang tergantung dari bagaimana manusia memprogramnya dan measukkan data, seperti Lawgeex, telah dikonsultasikan dan dilatih dengan professor hukum dari Universitas Stanford, Sekolah Hukum Universitas Duke, dan Universitas California. Lihat: Lawgeex, “AI vs. Lawyer: The Ultimate Showdown”, https://www.lawgeex.com/AIvsLawyer/, diakses 23 Oktober 2018 .

12 Ibid.

13 Algoritma secara singkat dapat didefinisikan sebagai langkah-langkah sistematis dan logis dalam menyelesaikan suatu masalah. Dengan konsep algoritma = logika + kontrol, maka suatu permasalahan diselesaikan secara sistematis, logis dan bisa diuji benar atau salahnya. Algoritma merupakan prosedur logis, urutan operasi yang bisa disimulasikan oleh sebuah sistem sehingga sangat penting bagi komputer mengolah data, dan menggerakan mesin kercerdasan untuk terus belajar hingga kian cerdas dari asupan data. Lebih jauh pembahasan tentang algoritma lihat Fernando Lafrate, 2018, Artificial Intelligence and Big Data: The Birth of New Intelligence, ISTE Ltd and John Wiley \& Sons, Inc., United States, hlm. 33-34. Lihat pula Wolfgang Ertel, 2017, Introduction to Artificial Intelligence, Springer, hlm. 75.

14 Sarah Finch, "5 Technological Disruptions In The Legal Sector", https://disruptionhub.com/5-technological-disruptions-in-the-legal-sector/, diakses 22 Agustus 2019. 
Dalam konteks Indonesia, regulasi saat ini hanya mengakui konsultan hukum pasar modal yang tergabung dalam Himpunan Konsultan Hukum Pasar Modal (HKHPM). ${ }^{15}$ Akankah peraturan yang kita miliki bertahan atau adaptif dengan era disrupsi yang tidak dapat dilawan? Regulasi ini "mungkin" kelak mengandung persoalan karena bagaimana mungkin regulasi tersebut mengatur mesin kecerdasan sebagai subyek hukum dan hanya mengakui apabila ia "bekerja" untuk konsultan HKHPM. Tegasnya, kehadiran mesin kecerdasan juga merupakan ancaman bagi profesi konsultan hukum pasar modal.

Keempat, mesin kecerdasan buatan juga menjadi ancaman bagi profesi hukum yang menjalankan hukum secara mekanis. Cara berhukum mekanis dipopulerkan oleh Langdell yang menciptakan metode kasus (case method) yang melatih kemahiran hukum mahasiswanya mengupas perkara yang diputus pengadilan. ${ }^{16}$ Pembelajaran model hukum mekanis ini karena Langdell memandang bekerjanya ilmu hukum sama dengan ilmu fisika yang bekerja atas dasar hubungan kausal. ${ }^{17}$ Sebagaimana ilmuwan fisika bekerja di laboratorium untuk menemukan hubungan sebab akibat, maka para yuris melakukan analisis-analisis perkara dalam putusan pengadilan di perpustakaan juga untuk menemukan hubungan kausal yakni antara perbuatan hukum dan akibat hukumnya. ${ }^{18}$

Pendidikan hukum yang menekankan kemahiran hukum semakin dianggap relevan. Terlebih lulusan fakultas hukum di Indonesia menghadapi persaingan global, terutama pasar bebas yang memungkinkan lahan bagi beroperasinya hukum sudah mendunia. Batas-batas konvensional suatu negara mencair dan tidak menjadi penghalang advokat asing bekerja di manapun. Konsumen, tentu hanya menggunakan sarjana hukum yang mempunyai keterampilan hukum.

Berangkat dari permintaan pasar (market demand) itu, sejumlah lembaga pendidikan tinggi hukum melakukan reorientasi pembelajaran hukum dengan mendidik dan menyiapkan lulusan yang berkualifikasi siap pakai yakni para praktisi hukum yang nantinya berkiprah sebagai advokat, hakim, jaksa, notaris, dan sebagainya. ${ }^{19}$ Pendidikan hukum profesi lebih bertumpu pada vocational training untuk mencetak legal craftsmanship dan legal mechanic. ${ }^{20}$ Persoalannya, di era digital, teknologi yang lebih canggih akan menggantikan sesuatu yang bersifat teknologi pula. Artinya, profesi hukum yang cara berhukumnya mekanis atau mirip teknologi akan dikalahkan dan digantikan oleh mesin kecerdasan buatan. Mesin kecerdasan buatan bekerja berdasarkan program Case Based Reasoning (CBR), yakni suatu pendekatan yang diprogram untuk mendapatkan solusi dengan menggunakan acuan solusi problem-problem terdahulu untuk memecahkan problem yang baru. Jadi, CBR memecahkan masalah baru dengan menggunakan solusi masalah yang pernah terjadi sebelumnya yang serupa. CBR dapat diibaratkan memindahkan database kasus-kasus yang telah dimiliki oleh seorang pakar ke dalam hardisk komputer untuk dipakai menyelesaikan kasus baru yang serupa. ${ }^{21}$ Dengan mesin kecerdasan buatan, masyarakat

15 Peraturan Otoritas Jasa Keuangan Nomor 66/POJK.04/2017 tentang Konsultan Hukum Yang Melakukan Kegiatan di Pasar Modal, Lembaran Negara Republik Indonesia Tahun 2017 Nomor 287, Tambahan Lembaran Negara Republik Indonesia Nomor 6155.

16 Cara pandang Langdell dalam memahami hukum menurut Soetandyo Wigjosoebroto sebagai legal science atau mechanistic jurisprudence. Lihat: Soetandyo Wignjosoebroto, "Positivisme: Paradigma ke Arah Lahirnya Teori Sosial dan Teori Hukum Modern berikut Kritik-kritiknya", Makalah, disampaikan dalam Diskusi Lingkar Belajar Huma 2010.

17 Langdell percaya bahwa hukum adalah "science" sebagaimana dinyatakan dalam bukunya "it is indispensable to establish at least two things; first that science is a science; secondly that all the available materials of that science are contained in printed books.... (the library is...to us all that the laboratories of the university are to chemists and physicists, all that the museum of natural history is to the zoologists, all that the botanical garden is to the botanists....”. Lihat Cristopher Langdell, 1871, A Selection of Cases on the Law of Contracts: Part 1.h Brown \& Company, Boston Little.

18 C. Langdell, "Harvard Celebration Speeches", Law Quaterly Review, No. 3, 1887, hlm. 123- 125.

19 Sebagai contoh SK Mendikbud 0325/U/1994 yang memasukan satu kelompok mata kuliah tentang Pendidikan dan Latihan Kemahiran Hukum.

20 Esmi Warassih, 2005, Pranata Hukum: Sebuah Telaah Sosiologis, Suryandaru Utama, Semarang, hlm. 25-30.

21 Agnar Aamodt, et al., "Case-Based Reasoning: Foundational Issues, Methodological Variations, and System Approaches", Artificial Intelligence Communications, Vol 7, No.1, 1994, hlm. 39-52 
pengguna jasa hukum cukup mengandalkan cakram disk berisi miliaran gygabite data, yang didalamnya tersimpan jutaan simulasi kasus dengan solusinya, sehingga tinggal klik, maka dalam sekejap semua pertanyaan hukum terjawab.

Keempat, ekspansi kecerdasan buatan juga diperkirakan merubah manajemen dan hukum acara di pengadilan, mungkin kelak tanpa perlu kehadiran fisik para pihak karena cukup melalui sarana telekonferensi. Seng Siew Lim, advokat dari OTP Law Corporation memperkirakan dengan perkembangan teknologi big data yang mampu menganalisiskompleksitasinformasi,maka artificial intelligence juga kelak mampu menggantikan peran hakim dalam memutus perkara. Apalagi pekerjaan hakim jauh lebih monoton ketimbang variasi jasa layanan hukum yang ditawarkan oleh advokat, sehingga Lim mengatakan, "Segera kita akan menghadapi mesin yang bisa memutuskan mana yang benar dalam sengketa hukum." 22

Kalimat yang disampaikan Lim bukan suatu ungkapan yang berlebihan karena di Uni Eropa sebuah sengketa kontraktual atau perdata apapun diputus oleh robot dengan Online Dispute Resolution (ODR). Mekanisme ODR disediakan oleh Komisi Eropa untuk memungkinkan konsumen dan pedagang di Uni Eropa atau Norwegia, Islandia, dan Liechtenstein untuk menyelesaikan perselisihan terkait pembelian barang dan jasa secara online tanpa pergi ke pengadilan. ${ }^{23}$ Artinya, potensi korban berikutnya adalah para hakim dan juga jaksa yang selama ini mengandalkan penalaran deduktif (silogisme). Konstruksi pengadilan, misalnya, yang mendudukan para pihak saling berhadapan, seolah para pihak sedang berdebat dalam pencarian kebenaran yang mendasar. Padahal, sesungguhnya mereka tidak sedang berdebat sama sekali karena fakta hukum (premis minor) harus dicocokkan pada unsur-unsur norma hukum yang diandaikan sebagai konsep kebenaran (premis mayor). Walaupun dari premis-premis itu lahir kesimpulan, namun kesimpulan itu tidak mengandung sesuatu yang baru melebihi apa yang telah ditentukan di dalam premis mayor.

Penalaran hukum juga menjadi target mesin kecerdasan buatan. ${ }^{24}$ Dalam melaksanakan penalaran, sebuah mesin kecerdasan buatan dapat menggunakan konversi silogisme dan proses penalaran deduktif ke dalam bentuk yang sesuai dengan manipulasi komputer. Hal ini merupakan sistem kaidah dan prosedur yang memungkinkan mesin kecerdasan bisa menarik inferensi dari berbagai premis dalam logika. Evolusi mesin kecerdasan buatan, misalnya, telah dikembangkan Computational Models of Legal Reasoning (CMLRs). Program CMLRs ini yang mampu melakukan analisis teks hukum, melakukan penalaran hukum, memberikan argumentasi hukum, hingga mampu memprediksi dan memberi jawaban atas sengketa hukum. ${ }^{25}$

Kelima, potensi korban mesin kecerdasan buatan selanjutnya adalah para akademisi dan peneliti hukum yang bekerja secara monodispliner atau menutup pintu kerja sama dengan ranah ilmu lain (interdisipliner). Cara berpikir monodisipliner mendapat pembenaran teoritik dari pemikiran Hans Kelsen yang terkenal dengan The Pure Theory of Law sebagai berikut:

"The Pure Theory of Law is a theory of positive law... It is called a "pure" theory of law, because it only describes the law and attempts to eliminate from the object of this description everything that is not strictly law: Its aim is to free the science of law from alien elements." 26

\footnotetext{
Hukumonline, Op. cit.

ODR, https://ec.europa.eu/consumers/odr/main/?event=main.home.howitworks, diakses 20 Januari 2019.

Anne von der Lieth Gardner, 1987, Artificial Intelligence Approach to Legal Reasoning, MIT Press, Cambridge, hlm. 1-2.

Kevin D. Ashley, 2017, Artificial Intelligence and Legal Analytics New Tools for Law Practice in the Digital Age, Cambridge University Press, Cambridge, hlm. 3-4.

26 Hans Kelsen, 1976, The Pure Theory of Law, Diterjemahkan oleh Max Knight, University of California Press, California, hlm. 1. Bandingkan dengan Andrei Marmor, "Exclusive Legal Positivism", dalam Jules L. Coleman, et al., 2002, The Oxford Handbook of Jurisprudence and Philosophy of Law, Oxford Press, Oxford, hlm. 104 - 124.

J.W. Harris, 1982, Law and Legal Science: An Inquiry into the Concepts Legal Rule and Legal System, Clarendon Press, Oxford, hlm. 24.
} 
Teori Hukum Murni ingin memisahkan dan membersihkan hukum dari anasir-anasir non hukum seperti moral dan fakta. ${ }^{27}$ Teori ini mempunyai pengaruh dengan derajat yang signifikan dalam pengembanan hukum, termasuk di Indonesia. Ilmu hukum dengan karakternya yang normatif diklaim sebagai sui generis (satu untuk jenisnya sendiri). ${ }^{28}$ Peter Mahmud Marzuki berpandangan bahwa ilmu hukum disebut sui generis karena tidak ada bentuk ilmu-ilmu lain yang dapat dibandingkan dengan ilmu hukum. Lebih lanjut Peter menegaskan bahwa sifat dari sui generis berarti ilmu hukum dengan karakternya yang normatif merupakan ilmu dari jenis tersendiri, sehingga pengelompokannya bukan berada pada pohon atau rumpun ilmu sosial dan ilmu humaniora. ${ }^{29}$

Menurut hemat Penulis, setiap ilmu termasuk ilmu hukum, mempunyai karakternya sendiri sehingga satu bidang ilmu membedakan dengan yang lain. Tetapi, jika ilmu hukum menutup pintu kerjasama dengan ilmu lain (interdisipliner) bukan hanya mengerdilkan ilmu hukum itu sendiri, juga mempercepat era paska manusia di bidang hukum. Hukum di masa depan semakin kompleks sehingga tidak cukup memadai meneliti dan menjelaskan fenomena hukum dengan satu pendekatan hukum doktrinal, melainkan perlu pendekatan yang interdisipliner. ${ }^{30}$

\section{Teknologi dan Nurani}

Paradigma adalah perjuangan kompetitif berbagai paradigma untuk mendapatkan legitimasi intersubjektif dari komunitas ilmuwan. Paradigma yang memperoleh legitimasi akan tampil menjadi paradigma (P1). ${ }^{31}$ Apabila berbagai permasalahan mampu diantisipasi dan dipecahkan oleh $\mathrm{P} 1$, maka ia menjadi kebenaran yang mapan (normal science). Hal ini merupakan periode di mana paradigma menjadi kebenaran mapan yang menjalankan pengetahuan untuk melakukan pembenaran berdasarkan paradigma yang dianut. ${ }^{32}$

Masyarakat terus berkembang, ada masalahmasalah baru yang muncul. Ketika suatu paradigma tidak dapat menyelesaikan masalah-masalah tersebut, paradigma pada periode waktu tertentu akan mengalami anomali, atau dalam konteks ini disebut disrupsi. Anomali diilustrasikan sebagai situasi pada saat paradigma yang sedang dominan pada saat tertentu, mengalami kesulitan atau kegagalan untuk menjelaskan berbagai fakta baru yang muncul dalam situasi nyata. ${ }^{33}$ Paradigma lama (P1) dianggap sudah tidak sanggup untuk memberikan kontribusi nyata dalam pemecahan berbagai masalah, sehingga ketika anomali (An) itu terus semakin melebar, terjadilah krisis, kepercayaan terhadap paradigma yang sebelumnya dominan menjadi terkikis. ${ }^{34}$

27 Stanley L. Paulson, “Continental Normativism and Its British Counterpart: How Different are they?”, Ratio Juris, Vol.6, Issue 3, December, 1993, hlm. 227-244. Bandingkan dengan Kaarlo Tuori, 2016, Critical Legal Positivism, Routledge, London, hlm. 25.

28 Peter Mahmud Marzuki, 2009, Pengantar Ilmu Hukum, Prenada Media Group, Jakarta, hlm. 27- 35.

29 Ilmu hukum sebagai sui generis masih pada klaim ontologis dibanding sebuah argumentasi epistemologis dan metodologis. Karena ilmu hukum tidak turun dari ruang hampa, seharusnya dijelaskan bagaimana historisitas diskursif (bagaimana asal usul ilmu hukum hingga bagaimana 'perpisahan' dengan ilmu lain) menyebabkan ia (ilmu hukum) menjadi ilmu yang tersendiri (sui generis). Namun bila hanya mengatakan ilmu hukum itu berbeda dengan ilmu yang lain, sama halnya dengan mengatakan bahwa warna abu-abu, dinamakan demikian karena dia berbeda dengan hitam atau putih. Padahal bisa saja abu-abu merupakan kombinasi antara hitam dan putih. Dengan mengatakan warna itu adalah abu-abu dengan alasan tidak suka hitam dan putih, maka penyebutan warna abu-abu tidak memiliki signifikansi apapun. Sama halnya dengan menyebut ilmu hukum adalah sui generis karena tidak menyukai ilmu sosial, maka secara keilmuwan tidak mempunyai signifikansi apapun.

30 Terry Hutchinson, "Legal Research in The Fourth Industrial Revolution", Monash University Law Review, Vol. 43, No. 2, 2017, hlm. 573. Bandingkan dengan Alexander Somek, 2017, The Legal Relation Legal Theory After Legal Positivism, Cambridge University Press, Cambridge, hlm. 4. Sementara Adriaan Bedner mengkritik pendekatan hukum murni di Indonesia, "the extreme limitations in the use of sources of law, the objective to teach 'pure' law leads to sterile, theoretical approach, that is neither academically challenging, nor very useful for practitioners". Lihat Adriaan Bedner, "The Future of Legal Education in Indonesia", Makalah, disampaikan dalam International Conference on Legal Education in Southeast Asia, 1-2 October 2013.

31 Thomas Kuhn, 1962, The Structure of Scientific Revolutions, The University of Chicago Press, Chicago. hlm. 10.

Ibid., hlm. 23

Ibid., hlm. 52

Ibid., hlm. 66 
Disrupsi memaksa orang mempertanyakan kembali secara radikal dasar-dasar ontologis, epistemologis, dan nilai-nilai yang selama ini dianutnya hingga persoalan metodologis. ${ }^{35}$ Pada fase ini terjadi perselisihan paradigma (the battle of paradigm) dan apabila tawaran paradigma baru memenangkan kompetisi maka paradigma tersebut akan mendapat legitimasi dari komunitas keilmuwan yang pada gilirannya akan mendorong lahirnya paradigma baru yang sama sekali berbeda dengan paradigma sebelumnya (P2). ${ }^{36}$

Revolusi industri 4.0 telah mengubah cara orang-orang berinteraksi dengan hukum. Di bidang hukum, firma hukum, kantor pengadilan, kepolisian dan kejaksaan, akan semakin tergantung dan membutuhkan banyak legal information engineers. ${ }^{37}$ Kita tidak mungkin berjalan ke arah yang berlawanan dengan perkembangan teknologi. Pekerjaan hukum sebagian memang serupa dengan cara kerja teknologi sehingga pekerjaan hukum bisa tergantikan oleh mesin kecerdasan buatan. Pada bagian ini, mesin kecerdasan buatan akan dikolaborasikan atau bekerja sama dengan para profesi hukum. Hal ini bertujuan agar kedua kecerdasan antara manusia dengan mesin kecerdasan buatan dapat dipadukan untuk mencapai hasil yang jauh lebih baik, cepat, dan akurat. ${ }^{38}$

Tetapi tidak semua pekerjaan hukum sesederhana seperti bekerjanya mesin. Dalam kasus hukum yang di dalamnya sarat dengan pergulatan antara kepastian, kemanfaatan dan keadilan, mesin kecerdasan buatan memang mampu menjamin kepastian hukum dengan tingkat akurasi tinggi, tetapi mesin tidak mempunyai kepekaan untuk mendekatkan hukum pada keadilan karena keadilan tidak bisa diukur secara secara saintifik.
Untuk mendekatkan hukum pada keadilan diperlukan hakim manusia yang memutus tidak hanya berdasarkan logika hukum semata melainkan juga kepekaan nurani. Hipotesisnya, berhukum dengan nurani akan menghasilkan kualitas putusan hukum yang berbeda dibandingkan yang bekerja hanya berdasarkan penalaran hukum semata. Dalam kasus-kasus yang dilematis (hard cases) seperti kasus Prita dan Nuril (kasus ITE) di mana jika perkara itu ditangani dengan hati nurani atau tanpa nurani, mempunyai derajat kualitas keadilan yang berbeda dalam putusannya.

Di tengah kebangkitan mesin kecerdasan buatan, penanda yang membedakan antara manusia dengan robot adalah manusia mempunyai hati nurani yang hingga sekarang belum mampu digantikan oleh mesin kecerdasan buatan. Menurut hemat Penulis, ekspansi mesin kecerdasan buatan tidak hanya menggeser paradigma hukum, melainkan kelak juga merubah konstruksi hukum. Misalnya, pengadilan tingkat pertama kelak ditangani mesin kecerdasan buatan ${ }^{39}$ dengan putusan yang lebih menekankan kepastian hukum dengan tingkat akurasi tinggi. Apabila putusan dirasakan tidak adil, maka para pihak dapat banding di mana majelis hakim, pengacara, jaksa adalah manusia.

Dengan konstruksi hukum seperti itu, kedudukan profesi hukum manusia didudukan lebih tinggi dibanding mesin kecerdasan karena menyadari kemampuan mesin kecerdasan terbatas hanya memberikan "kepastian hukum". Tugas selanjutnya, diperlukan peran profesi hukum manusia yang mencari dan menemukan keadilan yang hidup di masyarakatnya, guna mendekatkan hukum pada keadilan secara bijaksana. Konsekuensinya, para profesi hukum masa depan adalah bukan sembarang

\footnotetext{
Ibid., hlm. 77.

Ibid., hlm. 111.

Richard Susskind, 2017, Tomorrow's Lawyers: An Introduction Your Future, Oxford University Press, Oxford, hlm. 123-124.

V.R. Benjamins, et al., "Iuriservice: Intelligent Frequently Asked Questions System to Assist Newly Appointed Judges", dalam V.R. Benjamins, et al., 2005, Law and the Semantic Web Legal Ontologies, Methodologies, Legal Information Retrieval, and Applications, Springer-Verlag Berlin, Heidelberg, hlm. 201.

39 Pertanyaan-pertanyaan yang segera muncul adalah; apakah kelak hakim robot adalah subyek hukum? Kalau ada kesalahan dalam membuat putusan atau melakukan suatu tindakan hukum, siapa yang bertanggung jawab? Apakah hakim robotnya atau programmer? Dari mana robot mendapat wewenang sebagai hakim? Bagaimana peraturan perundang-undangan dan regulator menghadapi realitas ini? Inilah tantangan masa depan hukum.
} 
manusia, melainkan orang-orang terpilih dan tidak diragukan lagi integritas dan kecerdasan nuraninya. Ranah pendidikan hukum yang sebelumnya mengajarkan kemahiran hukum, perlu ditambahkan pendidikan yang padat nilai seperti filsafat keadilan disamping etika profesi untuk mengasah kecerdasan nurani. Dengan pengembanan hukum yang seperti ini, maka para profesi hukum manusia di era milenial tetap sebagai pemimpin peradaban hukum di tengah disrupsi dan ekspansi mesin kecerdasan buatan.

\section{Penutup}

Di era digital, teknologi yang lebih canggih akan menggantikan sesuatu yang bersifat teknologi pula, maka profesi hukum yang cara berhukumnya mekanis atau mirip bekerjanya teknologi akan digantikan oleh mesin kecerdasan buatan yang tingkat akurasi dan kepastian hukumnya lebih tinggi dibanding dengan kemampuan profesi hukum manusia. Pada fase revolusi industri 4.0, kemajuan digital merubah paradigma dan cara orang berhukum, orang tidak perlu konsultasi datang ke kantor hukum, karena mesin kecerdasan buatan menyediakan jawaban atas berbagai permasalahan hukum. Bahkan, firma hukum, pengadilan, kepolisian dan kejaksaan, juga akan semakin tergantung pada mesin kecerdasan buatan. Performa mesin kecerdasan buatan terbukti mampu lebih cepat dan akurat dibandingkan profesi hukum manusia dalam mengidentifikasi dan menganalisis masalah hukum. Tentu, bukan berarti ia langsung dapat mengganti semua peran profesi hukum manusia. Mesin kecerdasan sebatas memberikan kepastian hukum, sementara dalam kasus hukum tertentu sarat pergulatan antara kepastian, kemanfaatan dan keadilan. Keadilan bukan soal algoritma, melainkan lebih pada hati nurani, kepekaan pada nilai-nilai kemanusiaan, dan perspektif kritis akan realitas. Tegasnya, untuk mendekatkan hukum pada keadilan, diperlukan profesi hukum manusia yang berintegritas dan mempunyai kecerdasan nurani.

\section{DAFTAR PUSTAKA}

\section{A. Buku}

Araszkiewicz, Michal, et al., 2013, Coherence: Insights from Philosophy, Jurisprudence and Artificial Intelligence, Springer.

Ashley, Kevin D., 2017, Artificial Intelligence and Legal Analytics New Tools for Law Practice in the Digital Age, Cambridge University Press, Cambridge.

Ertel, Wolfgang, 2017, Introduction to Artificial Intelligence, Springer.

Gardner, Anne von der Lieth, 1987, Artificial Intelligence Approach to Legal Reasoning, MIT Press, Cambridge.

Harris, J.W., 1982, Law and Legal Science: An Inquiry into the Concepts Legal Rule and Legal System, Clarendon Press, Oxford.

Kelsen, Hans, 1976, The Pure Theory of Law, Diterjemahkan oleh Max Knight, University of California Press.

Kuhn, Thomas, 1962, The Structure of Scientific Revolutions, The University of Chicago Press, Chicago.

Lafrate, Fernando, 2018, Artificial Intelligence and Big Data: The Birth of New Intelligence, ISTE Ltd and John Wiley \& Sons, Inc., United States.

Langdell, Cristopher, 1871, A Selection of Cases on the Law of Contracts: Part 1. Brown \& Company, Boston Little.

Marzuki, Peter Mahmud, 2009, Pengantar Ilmu Hukum, Prenada Media, Jakarta.

Somek, Alexander, 2017, The Legal Relation Legal Theory After Legal Positivism, Cambridge University Press, Cambridge.

Susskind, Richard, et al., 2015, The Future of

The Professions: How Technology Will 
Transform the Work of Human Experts, Oxford University Press, Oxford. , 2017, Tomorrow's Lawyers: An Introduction Your Future, Oxford University Press, Oxford.

Tuori, Kaarlo, 2016, Critical Legal Positivism, Routledge, London.

Warassih, Esmi, 2005, Pranata Hukum: Sebuah Telaah Sosiologis, Suryandaru Utama, Semarang.

\section{B. Artikel Jurnal}

Aamodt, Agnar, et al., "Case-Based Reasoning: Foundational Issues, Methodological Variations, and System Approaches", Artificial Intelligence Communications, Vol 7, No.1, 1994.

Hutchinson, Terry, "Legal Research in The Fourth Industrial Revolution", Monash University Law Review, Vol. 43, No. 2, 2017.

Langdell, C., "Harvard Celebration Speeches", Law Quaterly Review, No. 3, 1887.

Paulson, Stanley L., "Continental Normativism and Its British Counterpart: How Different are they?", Ratio Juris, Vol.6, No. 3, December, 1993.

Rhyne, Charles S., "The Computer Will Speed a Law-Full World", American Bar Association Journal, Vol. 53, May 1967.

\section{Makalah}

Bedner, Adriaan, "The Future of Legal Education in Indonesia", Makalah, disampaikan dalam International Conference on Legal Education in Southeast Asia, 1-2 October 2013.

Wignjosoebroto, Soetandyo, "Konsep Hukum, Tipe dan Metode Penelitiannya," Makalah, disampaikan pada Penataran Metodologi Penelitian Hukum di Fakultas Hukum Universitas Hasanudin, Makasar, 4-5 Februari 1994.
, "Positivisme: Paradigma ke Arah Lahirnya Teori Sosial dan Teori Hukum Modern berikut Kritik-kritiknya", Makalah, disampaikan dalam Diskusi Lingkar Belajar Huma 2010.

\section{Artikel dalam Antologi dengan Editor}

Benjamins, V.R., et al., "Iuriservice: Intelligent Frequently Asked Questions System to Assist Newly Appointed Judges", dalam Benjamins, V.R., et al., 2005, Law and the Semantic Web Legal Ontologies, Methodologies, Legal Information Retrieval, and Applications, Springer-Verlag Berlin, Heidelberg.

Marmor, Andrei, "Exclusive Legal Positivism", dalam Coleman, Jules L., et al., 2002, The Oxford Handbook of Jurisprudence and Philosophy of Law, Oxford Press, Oxford.

\section{E. Artikel Koran}

Turner, Karen, "Meet "Ross" The Newly Hired Legal Robot", The Washington Post, 16 Mei 2016.

\section{F. Internet}

Finch, Sarah, "5 Technological Disruptions In The Legal Sector", https://disruptionhub.com/5technological-disruptions-in-the-legalsector/, diakses 22 Agustus 2019.

Hukumonline, "Artificial Intelligence dalam Industri Hukum, Menyongsong Masa Depan Dunia Hukum Tanpa Hakim dan Lawyer?", https://www.hukumonline.com/berita/baca/ lt5ac7289c0b372/artificial-intelligencedalam-industri-hukum--menyongsong-masadepan-dunia-hukum-tanpa-hakim-danlawyer, diakses 12 November 2018.

Lawgeex, "AI vs. Lawyer: The Ultimate Showdown", https://www.lawgeex.com/ AIvsLawyer/, diakses 23 Oktober 2018.

ODR, https://ec.europa.eu/consumers/odr/ main/? event $=$ main. home. howitworks, diakses 20 Januari 2019. 


\section{G. Peraturan Perundang-undangan}

Peraturan Otoritas Jasa Keuangan Nomor 66/ POJK.04/2017 tentang Konsultan Hukum Yang Melakukan Kegiatan di Pasar Modal, Lembaran Negara Republik Indonesia Tahun 2017 Nomor 287, Tambahan Lembaran Negara Republik Indonesia Nomor 6155.

\section{H. Hasil Wawancara}

Hasil Wawancara dengan Burhanudin, Advokat AB \& Partners, pada 17 Desember 2018.

Hasil Wawancara dengan Nur Saifur Rauf, Advokat Nur Saifur Rauf, S.H. \& Partners, pada 20 Desember 2018.

Hasil Wawancara dengan T.M. Luthfi Yazid, Direktur InLaw Center, pada 5 Januari 2019. 